\title{
RESPONSE OF SUGAR BEET PLANTS TO DIFFERENT COMPOST TYPES AND BORON SPRAYING AND THEIR EFFECT ON GROWTH CHARACTERS AND QUALITY UNDER RAS SUDR GONDITIONS \\ Soliman,M. E. ${ }^{\star}$; Mona M.A. Hammada** and Asha E. Abd El-Nabi ${ }^{\star \star}$ \\ * Institute of Environmental Studies and Researches Ain Shams University \\ ** Environmental Pollution Unit, Plant Ecology and Ranges Department, Desert Research Center
}

\begin{abstract}
Two field experiments were carried out in Ras Sudr Research Station, Desert Research Center, at South Sinai Governorate, Egypt during two successive growing winter seasons i.e. 2011/2012 and 2012/2013 to study the effect of nine treatments of compost produced from animal waste, town refuse and plant waste applied at three rates $\left(10,20\right.$ and $30 \mathrm{~m}^{3} / \mathrm{fed}$.) and three rates of foliar application of boron (control, 0.4 and $0.6 \mathrm{~g} / \mathrm{L}$.) and their interactions on growth (leaf area, root length, root diameter and total soluble solids (T.S.S \%), root fresh and dry weight / plant, top fresh and dry weight / plant) and chemical composition (sugar, juice purity and crude protein \%) of sugar beet plants. Split plot design was used. The results indicated that the highest values of growth parameters were recorded in plants treated with $30 \mathrm{~m}^{3} / \mathrm{fed}$. compost produced from animal waste in the first and second seasons. There were significant differences in chemical composition in sugar beet of roots among the tested sources of different compost types during first and second seasons. The highest values of sugar and crude protein percentage were recorded in plants treated with $30 \mathrm{~m}^{3} / \mathrm{fed}$. animal waste. While, the highest value of juice purity $\%$ was obtained by using $30 \mathrm{~m}^{3} / \mathrm{fed}$. of animal waste and $10 \mathrm{~m}^{3} / \mathrm{fed}$. town refuse at the first and second seasons, respectively. Boron foliar application showed significantly responses in the two seasons with respect to growth characters of sugar beet. Increasing boron foliar application from 0 to $0.4 \mathrm{~g} / \mathrm{L}$. increased growth characters of sugar beet at the first and second seasons. Application of boron spray exerted a significant increase in sugar, juice purity and crude protein \%. The interaction between compost types and boron foliar had a significant effect on leaf area in the first and T.S.S. \% in the second season. The interaction between different compost types and boron foliar had a significant effect on sugar, juice purity and crude protein $\%$.
\end{abstract}

Keywords: compost types, boron foliar, sugar beet, South Sinai, growth, chemical composition.

\section{INTRODUCTION}

Sugar beet crop has an important position in Egyptian crop rotation as winter crop not only in the fertile soils, but also in poor, saline alkaline and calcareous soils. Whereas, it could be economically grown in the newly reclaimed soils such as South Sinai of Egypt as one of the most tolerant crops to salinity and wide range of climates. Sugar beet being, often, the most important cash crop in the rotation, it leaves the soil in good conditions for the benefit of the following cereal crops. By-products of sugar production, 
such as pulp, molasses and lime, flow bath into agriculture to increase livestock production and improve soil fertility as well as provide various middle products as alcohol, forage and other many products.

Arid and semi-arid regions represent about $30 \%$ of the total global land surface, and could contribute significantly to the agricultural production, considering constraints limiting factors for growth and production were paved away. High salts concentration results in high osmotic potential of the soil solution, so the plant has to use more energy to absorb water. Under extreme salinity conditions, plants may be unable to absorb water and will wilt, even when the surrounding soil is saturated. When a plant absorbs water containing ions of harmful salts (e.g. sodium, chloride, excess of boron etc.), visual symptoms might appear, such as stunted plant growth, small leaves, marginal necrosis of leaves or fruit distortions.

Benefit from the remnants of cities and farm wastes that pollute the environment and recycled into compost and use it as fertilizer landslide in the cultivation of sugar beet plant. In this respect, Esawy et al. (2009) mentioned that the highest fruit and dry shoot weights of cucumber were in the plots treated with the plant compost compared to animal and mixed composts. However, El-Nagdi and Abd El Fattah (2011) showed that all plant residues, biofertilizer, and organic compost alone or in combination with biocides significantly increased fresh weight of roots and shoots of sugar beet plants. On the other hand, Luna et al. (2011) studied the effect of five compost i.e. compost $1(30 \%$ Sludge paper manufacturer $+30 \%$ Sludge soft drink manufacture $+30 \%$ Chili pepper residues $+10 \%$ Corn stubble ), compost 2 (0\% Sludge paper manufacturer $+35 \%$ Sludge soft drink manufacture + $55 \%$ Chili pepper residues $+10 \%$ Corn stubble ), compost 3 (45\% Sludge paper manufacturer $+25 \%$ Sludge soft drink manufacture $+25 \%$ Chili pepper residues $+5 \%$ Corn stubble ), compost $4(0 \%$ Sludge paper manufacturer $+0 \%$ Sludge soft drink manufacture $+75 \%$ Chili pepper residues $+25 \%$ Corn stubble ), compost 5 (45\% Sludge paper manufacturer $+45 \%$ Sludge soft drink manufacture $+0 \%$ Chili pepper residues $+10 \%$ Corn stubble ) and without compost on growth of bean plants. They found that compost 5 gave the highest growth compared with other treatments.

Boron is essential for many plant functions. Some of them are: maintaining a balance between sugars and starch, the translocation of sugar and carbohydrates. it is necessary for normal cell division, nitrogen metabolism, and protein formation. Several investigations concluded that increasing boron increased the growth and chemical composition of sugar beet and another crops has been well documented by Ibrahim (2006), Tabrizi et al. (2008), Abou EL-Yazied and Mady. (2012) and Aparna and Puttaiah. (2012).

The aim of this study is to evaluate the effect of nine compost treatments produced and three levels of boron spraying on growth and chemical composition of sugar beet (Beta vulgaris L.) grown in a calcareous soil at Ras Sudr conditions. 


\section{MATERIALS AND METHODS}

Two field experiments were carried out at the Experimental Farm of the Desert Research Center (DRC) at Ras Sudr region, South Sinai Governorate, during the successive winter seasons of 2011/2012 and $2012 / 2013$ to study the effect of two factors, i.e. compost types and boron on growth and chemical composition of sugar beet.

The soil of the location was highly calcareous and saline. Some physical and chemical analyses of the experiment soil are presented in Table (1). The physical and chemical analysis was carried out according to the methods described by Jackson (1970).

Table (1): Some physical and chemical analysis of the experimental soil.

\begin{tabular}{|c|c|c|c|c|c|c|c|c|c|c|c|}
\hline \multicolumn{12}{|c|}{ Physical analysis } \\
\hline \multicolumn{2}{|c|}{ Depth (cm) } & $\mathrm{CaCO}_{3} \%$ & \multicolumn{2}{|c|}{$\begin{array}{c}\text { Coarse } \\
\text { sand } \\
\%\end{array}$} & \multicolumn{2}{|c|}{$\begin{array}{c}\text { Fine sand } \\
\%\end{array}$} & $\begin{array}{c}\text { Silt } \\
\%\end{array}$ & $\begin{array}{l}\text { Total } \\
\text { sand }\end{array}$ & \multicolumn{2}{|c|}{ Clay } & Texture \\
\hline \multicolumn{2}{|l|}{$0-30$} & 55.85 & \multicolumn{2}{|c|}{54.51} & \multicolumn{2}{|c|}{$25.88^{\%}$} & 8.36 & 80.39 & \multicolumn{2}{|c|}{11.25} & Sandy \\
\hline \multicolumn{2}{|l|}{$30-60$} & 51.21 & \multicolumn{2}{|c|}{25.49} & \multicolumn{2}{|c|}{64.12} & 7.20 & 89.61 & \multicolumn{2}{|c|}{6.45} & $\begin{array}{l}\text { Sandy } \\
\text { loam }\end{array}$ \\
\hline \multicolumn{12}{|c|}{ Chemical analysis } \\
\hline \multirow{2}{*}{ 흐응 } & \multirow[b]{2}{*}{$\frac{T}{2}$} & \multirow[b]{2}{*}{ 엄 } & \multicolumn{5}{|c|}{ Soluble anions (meq / L) } & \multicolumn{4}{|c|}{ Soluble cations ( meq / L) } \\
\hline & & & $\mathrm{CO}_{3}^{--}$ & HC & & $\mathrm{SO}_{4}^{--}$ & $\mathrm{Cl}^{-}$ & $\mathrm{Ca}^{++}$ & $\mathrm{Mg}^{++}$ & $\mathrm{Na}^{+}$ & $\mathrm{K}^{+}$ \\
\hline $\begin{array}{l}0-30 \\
30-60\end{array}$ & $\begin{array}{l}7.7 \\
7.4 \\
\end{array}$ & $\begin{array}{l}4.77 \\
4.16 \\
\end{array}$ & $\begin{array}{l}0.00 \\
0.00\end{array}$ & & $\begin{array}{l}.00 \\
.00\end{array}$ & \begin{tabular}{|l|}
10.50 \\
16.10 \\
\end{tabular} & $\begin{array}{l}31.20 \\
22.50\end{array}$ & $\begin{array}{l}24.00 \\
16.83 \\
\end{array}$ & $\begin{array}{c}11.00 \\
6.00 \\
\end{array}$ & $\begin{array}{l}10.52 \\
17.80 \\
\end{array}$ & $\begin{array}{l}2.18 \\
0.97\end{array}$ \\
\hline
\end{tabular}

The experimental treatments

\section{A-Different compost types}

1- compost produced from animal waste at rates of $\left(10,20\right.$ and $\left.30 \mathrm{~m}^{3} / \mathrm{fed}\right)$.

2- compost produced from town refuse at rates of $\left(10,20\right.$ and $\left.30 \mathrm{~m}^{3} / \mathrm{fed}\right)$.

3 - compost produced from plant waste at rates of $\left(10,20\right.$ and $\left.30 \mathrm{~m}^{3} / \mathrm{fed}\right)$.

These amounts of mature compost were added to the soil after dividing plots, and then mixed with the soil in each plot before cultivation. The analysis of compost types are given in Table (2).

\section{B-Boron foliar application:}

1- Control (tap water)

2- $0.4 \mathrm{~g} / \mathrm{L}$.

3- $0.6 \mathrm{~g} / \mathrm{L}$.

Boron were applied as foliar application in the form of borax $\left(\mathrm{Na}_{2} \mathrm{~B}_{4}\right.$ $\mathrm{O}_{7} \cdot \mathrm{loH}_{2} \mathrm{O}, 11.3 \% \mathrm{~B}$ ) , was sprayed at two times, i.e. after 40 and 60 days from sowing with 400 liter / fed.

The design of experiment was split plot with four replication, each replicate included 27 treatments which were the combination between nine different compost types treatments and three treatments of boron. The main plots were devoted to the boron, while the sub-plots were occupied by 
compost types. The experimental plots area $10.5 \mathrm{~m}^{2}(3 \times 3.5 \mathrm{~m})$, consisting of 6 ridges, each of $50 \mathrm{~cm}$ width and $3.5 \mathrm{~m}$ length, $50 \mathrm{~cm}$ were between hills and four seeds were planted in each hill. Before sowing all plots received 150 $\mathrm{kg}$ calcium super phosphate / fed. $\left(15.5 \% \mathrm{P}_{2} \mathrm{O}_{5}\right)$ were added during seed-bed preparation before planting and was mixed with the surface layer. In addition, $150 \mathrm{~kg}$ ammonium sulphate / fed. $(20.5 \% \mathrm{~N})$ and $200 \mathrm{~kg}$ potassium sulphate / fed. $\left(48 \% \mathrm{~K}_{2} \mathrm{O}\right)$ were applied at two doses, the first and second dose were applied after one and two months from sowing, respectivly.

Table (2): Chemical analysis of compost types.

\begin{tabular}{|c|c|c|c|}
\hline Compost types & Animal wastes & Town refuses & Plant wastes \\
\hline \begin{tabular}{|l|} 
Temperature \\
\end{tabular} & 27.0 & 27.5 & 26.6 \\
\hline Carbon dioxide \% & 5.4 & 6.5 & 6.6 \\
\hline Moisture content & 52.5 & 56.9 & 55.4 \\
\hline $\mathrm{pH}$ & 6.9 & 7.6 & 7.4 \\
\hline EC dS/m & 5.1 & 7.1 & 5.5 \\
\hline Organic carbon \% & 30.9 & 27.3 & 31.2 \\
\hline Organic matter \% & 53.1 & 46.9 & 53.7 \\
\hline Nitrogen $\%$ & 1.07 & 0.88 & 0.96 \\
\hline $\mathrm{C} / \mathrm{N}$ ratio & 26.99 & 31.02 & 32.50 \\
\hline Phosphorus \% & 0.72 & 0.66 & 0.70 \\
\hline Potassium \% & 1.45 & 1.03 & 1.39 \\
\hline Cadmium (mg/kg) & 0.66 & 0.76 & 0.54 \\
\hline Lead $(\mathrm{mg} / \mathrm{kg})$ & 3.4 & 4.4 & 2.4 \\
\hline Copper $(\mathrm{mg} / \mathrm{kg})$ & 2.8 & 3.6 & 1.7 \\
\hline Zinc $(\mathrm{mg} / \mathrm{kg})$ & 96.4 & 112.8 & 86.4 \\
\hline Boron $(\mathrm{mg} / \mathrm{kg})$ & 1.59 & 2.61 & 1.35 \\
\hline
\end{tabular}

Sugar beet seeds of Gazelle variety (Beta vulgaris, L) were sown on $15^{\text {th }}$ of October in the two growing seasons (2011/2012 and 2012/2013), the plants were thinned to one plant per hill fifteen day after planting date. The experiment was irrigated immediately after sowing by water pumped from a well (3500 ppm). The analysis of irrigation water is given in Table (3).

Five plants were taken from each sub-plot at 180 days from sowing date to determine leaf area, root length, root diameter and total soluble solids (T.S.S. \%), also chemical composition was determined in roots. Sugar percentage was determined in the juice of the sugar beet root using Saccharimeter equipment on a lead acetate extract of fresh macerated roots according to the method of Le-Docte, (1927). Juice purity \% was determined according to Carruthers and Oldfield (1961) as a ratio between sucrose \% and T.S.S \%. Total nitrogen was determined by using micro-Kjeldahl method as described by Peach and Tracey (1956). Crude protein was calculated by multiplying total nitrogen by 6.25 .

\section{Statistical analysis:}

All data obtained from the experiment were subjected to the proper statistical analysis of variance of the split plot design according to the 
procedure outlined by Snedecor and Cochran (1969). Mean values of treatments were differentiated by using L.S.D at $5 \%$ level as mentioned by Steel (1960).

Table (3). Chemical analysis of the irrigation water.

\begin{tabular}{|c|c|c|c|c|c|c|c|c|c|c|}
\hline \multirow{2}{*}{\begin{tabular}{|l} 
salinity \\
$(\mathrm{ppm})$
\end{tabular}} & \multirow{2}{*}{$\mathrm{pH}$} & \multirow{2}{*}{$E C d S / m$} & \multicolumn{4}{|c|}{ Anions meq /L } & \multicolumn{4}{|c|}{ Cations meq /L } \\
\hline & & & $\mathrm{CO}_{3}^{--}$ & $\mathrm{HCO}_{3}^{-}$ & $\mathrm{SO}_{4}^{-}$ & $\mathrm{Cl}^{-}$ & $\mathrm{Ca}^{++}$ & $\mathrm{Mg}^{++}$ & $\mathrm{Na}^{+}$ & $\mathrm{K}^{+}$ \\
\hline 3500 & 7.8 & 5.47 & 0.00 & 2.55 & 81.23 & 16.22 & 23.65 & 19.18 & 65.62 & 0.45 \\
\hline
\end{tabular}

\section{RESULTS AND DISCUSSION}

\section{Effect of different compost types, boron foliar spraying and their interactions: \\ 1- Growth characteristics of sugar beet:}

Data presented in Tables (4 and 5) clearly indicate that there were significant differences in growth characters i.e. leaf area, root length, root diameter and total soluble solids \% (T.S.5\%), root fresh and dry weight / plant and top fresh and dry weight / plant of sugar beet between the tested sources of different compost types during both seasons. The highest values of growth characters were recorded in plants treated with $30 \mathrm{~m}^{3} /$ fed.of animal waste ( $75 \%$ organic manure $+25 \%$ plant residues) in the first and second seasons. The lowest value was obtained from $10 \mathrm{~m} 3 /$ fed. town refuse $(75 \%$ towns refuse $+12.5 \%$ organic manure $+12.5 \%$ plant residues) in two growing seasons. In all treatments, increasing compost production from 10 to $30 \mathrm{~m}^{3} / \mathrm{fed}$. increased growth characters. These results are in agreement with those obtained by Essam et al. (2011), Ismail and Mohamed (2012), El-Quesni et al. (2013) and Ramadan et al. (2013).

The results in Tables (6 and 7) indicate that boron foliar application showed significantly responses in two seasons in respect to leaf area, root length, root diameter, total soluble solids (T.S.5\%), root fresh and dry weight / plant and top fresh and dry weight / plant of sugar beet. Increasing boron foliar application from 0 to $0.4 \mathrm{~g} / \mathrm{L}$. increased growth characters of sugar beet at the first and second seasons. On the contrary, control treatment (nil boron treatment) gave the lowest value of all growth characters in the first and second seasons. These results are in harmony with those obtained by Abido (2012), Abou EL-Yazied and Mady. (2012), Aparna and Puttaiah. (2012) and Konthoujam et al. (2012). 
Table (4). Leaf area, root length, root diameter and total soluble solids of sugar beet at harvest as affected by compost types in 2011/2012 and 2012/2013 seasons at Ras Sudr.

\begin{tabular}{|c|c|c|c|c|}
\hline Characters & Leaf area $\left(\mathrm{cm}^{2}\right)$ & $\begin{array}{l}\text { Root length } \\
(\mathrm{cm})\end{array}$ & $\begin{array}{c}\text { Root diameter } \\
(\mathrm{cm})\end{array}$ & $\begin{array}{c}\text { Total soluble } \\
\text { solids (T.S.S\%) }\end{array}$ \\
\hline Compost types & \multicolumn{4}{|c|}{$2011 / 2012$} \\
\hline $10 \mathrm{~m}^{3}$ A.W & 3455 & 25.7 & 11.7 & 20.12 \\
\hline $20 \mathrm{~m}^{3}$ A.W & 3599 & 26.9 & 12.2 & 20.35 \\
\hline $30 \mathrm{~m}^{3}$ A.W & 3772 & 27.8 & 11.4 & 20.74 \\
\hline $10 \mathrm{~m}^{3}$ T.R & 2652 & 21.6 & 9.6 & 20.12 \\
\hline $20 \mathrm{~m}^{3}$ T.R & 2822 & 22.1 & 10.4 & 19.84 \\
\hline $30 \mathrm{~m}^{3}$ T.R & 3088 & 22.9 & 10.4 & 20.23 \\
\hline $10 \mathrm{~m}^{3} \mathrm{P} . \mathrm{W}$ & 2905 & 24.4 & 10.7 & 19.91 \\
\hline $20 \mathrm{~m}^{3}$ P.W & 3080 & 25.5 & 11.1 & 19.98 \\
\hline $30 \mathrm{~m}^{3}$ P.W & 3333 & 26.4 & 11.5 & 20.45 \\
\hline LSD at $5 \%$ & 42 & 0.7 & 0.7 & 0.37 \\
\hline \multicolumn{5}{|l|}{$2012 / 2013$} \\
\hline $10 \mathrm{~m}^{3}$ A.W & 3021 & 22.7 & 10.0 & 19.51 \\
\hline $20 \mathrm{~m}^{3}$ A.W & 3218 & 23.9 & 10.0 & 19.77 \\
\hline $30 \mathrm{~m}^{3}$ A.W & 3432 & 24.7 & 11.0 & 20.08 \\
\hline $10 \mathrm{~m}^{3}$ T.R & 2266 & 18.5 & 7.6 & 18.51 \\
\hline $20 \mathrm{~m}^{3}$ T.R & 2455 & 19.0 & 8.4 & 18.90 \\
\hline $30 \mathrm{~m}^{3}$ T.R & 2703 & 19.6 & 9.0 & 19.28 \\
\hline $10 \mathrm{~m}^{3}$ P.W & 2795 & 21.3 & 8.7 & 18.99 \\
\hline $20 \mathrm{~m}^{3}$ P.W & 2967 & 22.4 & 9.4 & 19.37 \\
\hline $30 \mathrm{~m}^{3}$ P.W & 3133 & 23.1 & 9.9 & 19.72 \\
\hline LSD at $5 \%$ & 33 & 0.8 & 0.5 & 0.07 \\
\hline
\end{tabular}

A.W = Animal waste $\quad$ T.R. = Town refuse $\quad$ P.W = Plant waste

Table (5). Root fresh and dry weight / plant and tops fresh and dry weight / plant of sugar beet at harvest as affected by compost types in 2011/2012 and 2012/2013 seasons at Ras Sudr.

\begin{tabular}{|c|c|c|c|c|}
\hline Characters & $\begin{array}{c}\text { Root fresh } \\
\text { weight / plant } \\
\text { (kg) }\end{array}$ & $\begin{array}{l}\text { Root dry weight } \\
\text { / plant (kg) }\end{array}$ & $\begin{array}{c}\text { Top fresh } \\
\text { weight / plant } \\
\text { (kg) }\end{array}$ & $\begin{array}{l}\text { Top dry weight / } \\
\text { plant (kg) }\end{array}$ \\
\hline Compost types & \multicolumn{4}{|c|}{$2011 / 2012$} \\
\hline $10 \mathrm{~m}^{3}$ A.W & 1.114 & 0.251 & 0.489 & 0.058 \\
\hline $20 \mathrm{~m}^{3}$ A.W & 1.255 & 0.287 & 0.532 & 0.064 \\
\hline $30 \mathrm{~m}^{3}$ A.W & 1.408 & 0.327 & 0.582 & 0.071 \\
\hline $10 \mathrm{~m}^{3}$ T.R & 0.790 & 0.170 & 0.420 & 0.047 \\
\hline $20 \mathrm{~m}^{3}$ T.R & 0.906 & 0.199 & 0.452 & 0.052 \\
\hline $30 \mathrm{~m}^{3}$ T.R & 1.021 & 0.227 & 0.486 & 0.057 \\
\hline $10 \mathrm{~m}^{3} \mathrm{P} . \mathrm{W}$ & 1.005 & 0.222 & 0.458 & 0.053 \\
\hline $20 \mathrm{~m}^{3}$ P.W & 1.123 & 0.251 & 0.489 & 0.058 \\
\hline $30 \mathrm{~m}^{3}$ P.W & 1.248 & 0.284 & 0.524 & 0.063 \\
\hline LSD at $5 \%$ & 0.102 & 0.025 & 0.723 & 0.004 \\
\hline \multicolumn{5}{|c|}{$2012 / 2013$} \\
\hline $10 \mathrm{~m}^{3}$ A.W & 0.914 & 0.198 & 0.314 & 0.037 \\
\hline $20 \mathrm{~m}^{3}$ A.W & 1.055 & 0.234 & 0.357 & 0.042 \\
\hline $30 \mathrm{~m}^{3}$ A.W & 1.208 & 0.277 & 0.407 & 0.049 \\
\hline $10 \mathrm{~m}^{3}$ T.R & 0.590 & 0.121 & 0.245 & 0.026 \\
\hline $20 \mathrm{~m}^{3}$ T.R & 0.706 & 0.148 & 0.277 & 0.030 \\
\hline $30 \mathrm{~m}^{3}$ T.R & 0.821 & 0.177 & 0.311 & 0.036 \\
\hline $10 \mathrm{~m}^{3}$ P.W & 0.805 & 0.171 & 0.283 & 0.031 \\
\hline $20 \mathrm{~m}^{3}$ P.W & 0.923 & 0.201 & 0.314 & 0.035 \\
\hline $30 \mathrm{~m}^{3}$ P.W & 1.048 & 0.234 & 0.349 & 0.041 \\
\hline LSD at $5 \%$ & 0.055 & 0.012 & 0.022 & 0.002 \\
\hline
\end{tabular}


Table (6). Leaf area, root length, root diameter and total soluble solids of sugar beet at harvest as affected by boron spraying in 2011/2012 and 2012/2013 seasons at Ras Sudr.

\begin{tabular}{|l|c|c|c|c|}
\hline Characters & Leaf area $\left(\mathbf{c m}^{2}\right)$ & $\begin{array}{c}\text { Root length } \\
\text { (cm) }\end{array}$ & $\begin{array}{c}\text { Root diameter } \\
\text { (cm) }\end{array}$ & $\begin{array}{c}\text { Total soluble } \\
\text { solids (T.S.5\%) }\end{array}$ \\
\hline Boron spraying & \multicolumn{4}{|c|}{$\mathbf{2 0 1 1 / 2 0 1 2}$} \\
\hline Control & 2954 & 22.3 & 9.1 & 20.54 \\
\hline $\mathbf{0 . 4}$ g / L. & 3423 & 26.4 & 12.5 & 19.71 \\
\hline $\mathbf{0 . 6}$ g / L. & 3192 & 25.7 & 11.4 & 20.33 \\
\hline LSD at 5\% & $\mathbf{6 8}$ & $\mathbf{1 . 0}$ & $\mathbf{1 . 1}$ & $\mathbf{0 . 1 6}$ \\
\hline \multicolumn{5}{|c|}{$\mathbf{2 0 1 2 / 2 0 1 3}$} \\
\hline Control & 2586 & 20.4 & 8.6 & 20.31 \\
\hline $\mathbf{0 . 4}$ g / L. & 3143 & 22.5 & 10.0 & 18.51 \\
\hline $\mathbf{0 . 6}$ g / L. & 2934 & 22.2 & 9.3 & 19.23 \\
\hline LSD at 5\% & $\mathbf{2 6 3}$ & $\mathbf{1 . 3}$ & $\mathbf{0 . 2}$ & $\mathbf{0 . 1 2}$ \\
\hline
\end{tabular}
A.W = Animal waste
T.R. $=$ Town refuse
P.W = Plant waste

Table (7). Root fresh and dry weight / plant and tops fresh and dry weight / plant of sugar beet at harvest as affected by compost types in 2011/2012 and 2012/2013 seasons at Ras Sudr.

\begin{tabular}{|l|c|c|c|c|}
\hline Characters & $\begin{array}{c}\text { Root fresh } \\
\text { weight / plant } \\
(\mathbf{k g})\end{array}$ & $\begin{array}{c}\text { Root dry } \\
\text { weight / plant } \\
\mathbf{( k g )}\end{array}$ & $\begin{array}{c}\text { Top fresh } \\
\text { weight / plant } \\
(\mathbf{k g})\end{array}$ & $\begin{array}{c}\text { Top dry } \\
\text { weight / plant } \\
(\mathbf{k g})\end{array}$ \\
\hline boron spraying & \multicolumn{4}{|c|}{$\mathbf{2 0 1 1 / 2 0 1 2}$} \\
\hline Control & 0.927 & 0.204 & 0.390 & 0.045 \\
\hline $\mathbf{0 . 4}$ g / L. & 1.245 & 0.285 & 0.594 & 0.072 \\
\hline $\mathbf{0 . 6}$ g / L. & 1.118 & 0.251 & 0.494 & 0.058 \\
\hline LSD at 5\% & $\mathbf{0 . 2 0 4}$ & $\mathbf{0 . 0 5 2}$ & $\mathbf{0 . 0 0 9}$ & $\mathbf{0 . 0 0 4}$ \\
\hline \multicolumn{5}{|c|}{$\mathbf{2 0 1 2 / 2 0 1 3}$} \\
\hline Control & 0.677 & 0.143 & 0.240 & 0.027 \\
\hline $\mathbf{0 . 4}$ g / L. & 1.095 & 0.244 & 0.394 & 0.046 \\
\hline $\mathbf{0 . 6}$ g / L. & 0.918 & 0.200 & 0.319 & 0.036 \\
\hline LSD at 5\% & $\mathbf{0 . 0 2 4}$ & $\mathbf{0 . 0 0 6}$ & $\mathbf{0 . 0 7 2}$ & $\mathbf{0 . 0 0 8}$ \\
\hline
\end{tabular}

Results in Tables ( 8 and 9) indicate that the interaction between compost types and boron foliar was insignificant effect on root length, root diameter, root fresh and dry weight plant and top fresh weight / plant of sugar beet in the two growing seasons. While, leaf area was significant in the first season, also total soluble solid and top dry weight / plant were significant during second season. In this respect, the combination of $30 \mathrm{~m}^{3} / \mathrm{fed}$. animal waste and boron spraying at $0.4 \mathrm{~g} / \mathrm{L}$. recorded the maximum values of all growth characters of sugar beet plant in 2011/2012 and 012/2013 seasons. While, under control (without fertilizer) for boron and $30 \mathrm{~m}^{3} /$ fed. town refuse gave the minimal values of growth characters in the two growing seasons. 
Table (8). Leaf area, root length, root diameter and total soluble solids of sugar beet at harvest as affected by interaction in 2011/2012 and 2012/2013 seasons at Ras Sudr.

\begin{tabular}{|c|c|c|c|c|c|c|c|c|c|}
\hline \multirow{2}{*}{\multicolumn{2}{|c|}{ Interaction }} & \multicolumn{2}{|c|}{ Leaf area $\left(\mathrm{cm}^{2}\right)$} & \multicolumn{2}{|c|}{$\begin{array}{l}\text { Root length } \\
\text { (cm) }\end{array}$} & \multicolumn{2}{|c|}{$\begin{array}{l}\text { Root diameter } \\
\text { (cm) }\end{array}$} & \multicolumn{2}{|c|}{$\begin{array}{c}\text { Total soluble } \\
\text { solids (T.S.5\%) }\end{array}$} \\
\hline & & $\begin{array}{l}2011 / \\
2012\end{array}$ & $\begin{array}{l}2012 / \\
2013\end{array}$ & $\begin{array}{c}2011 / \\
2012\end{array}$ & $\begin{array}{c}2012 / \\
2013\end{array}$ & $\begin{array}{l}2011 / \\
2012\end{array}$ & $\begin{array}{l}2012 / \\
2013\end{array}$ & $\begin{array}{l}2011 / \\
2012\end{array}$ & $\begin{array}{l}2012 / \\
2013\end{array}$ \\
\hline \multirow{3}{*}{$\begin{array}{l}10 \mathrm{~m}^{3} \\
\text { A.W }\end{array}$} & Control & 3154 & 2615 & 23.8 & 21.8 & 9.9 & 9.2 & 20.29 & 20.59 \\
\hline & $0.4 \mathrm{~g} / \mathrm{L}$. & 3712 & 3297 & 27.1 & 23.3 & 13.2 & 11.0 & 19.62 & 18.70 \\
\hline & $0.6 \mathrm{~g} / \mathrm{L}$. & 3500 & 3150 & 26.1 & 23.1 & 12.1 & 9.2 & 20.43 & 19.26 \\
\hline \multirow{3}{*}{$\begin{array}{l}20 \mathrm{~m}^{3} \\
\text { A.W }\end{array}$} & Control & 3320 & 2897 & 25.1 & 23.1 & 10.1 & 9.6 & 20.74 & 20.74 \\
\hline & $0.4 \mathrm{~g} / \mathrm{L}$. & 3818 & 3499 & 28.3 & 24.6 & & 11.0 & 20.02 & 19.00 \\
\hline & $0.6 \mathrm{~g} / \mathrm{L}$. & 3659 & 3259 & 27.2 & 23.9 & 12.7 & 9.6 & 20.28 & 19.58 \\
\hline \multirow{3}{*}{$\begin{array}{l}30 \mathrm{~m}^{3} \\
\text { A.W }\end{array}$} & Control & 3520 & 3118 & 25.4 & 23.4 & 10.4 & 10.0 & 21.05 & 20.95 \\
\hline & $0.4 \mathrm{~g} / \mathrm{L}$. & 4012 & 3650 & 29.5 & 25.4 & 14.2 & 12 & 20.37 & 19.37 \\
\hline & $0.6 \mathrm{~g} / \mathrm{L}$. & 3784 & 3529 & 28.6 & 25.2 & 9.7 & 10.0 & 20.80 & 19.93 \\
\hline \multirow{3}{*}{$\begin{array}{ll}10 \mathrm{~m}^{3} \\
\text { T.R }\end{array}$} & Control & 2429 & 2000 & 19.7 & 17.6 & 7.2 & 6.6 & 20.47 & 19.51 \\
\hline & $0.4 \mathrm{~g} / \mathrm{L}$. & 2889 & 2500 & 23.1 & 19.1 & 10.9 & 8.3 & 19.55 & 17.56 \\
\hline & $0.6 \mathrm{~g} / \mathrm{L}$. & 2637 & 2298 & 22.0 & 18.7 & 10.7 & 6.6 & 20.34 & 18.44 \\
\hline \multirow{3}{*}{$\begin{array}{l}20 \mathrm{~m}^{3} \\
\text { T.R }\end{array}$} & Control & 2602 & 2197 & 20.0 & 18.1 & 8.1 & 7.7 & 20.21 & 19.73 \\
\hline & $0.4 \mathrm{~g} / \mathrm{L}$. & 3061 & 2750 & 23.5 & 19.5 & 11.5 & 9.0 & 19.26 & 17.95 \\
\hline & $0.6 \mathrm{~g} / \mathrm{L}$. & 2802 & 2419 & 22.9 & 19.4 & 11.5 & 7.7 & 20.04 & 19.02 \\
\hline \multirow{3}{*}{\begin{tabular}{|ll}
$30 \mathrm{~m}^{3}$ \\
T.R
\end{tabular}} & Control & 2865 & 2490 & 20.6 & 18.5 & 8.7 & 8.2 & 20.64 & 20.25 \\
\hline & $0.4 \mathrm{~g} / \mathrm{L}$. & 3338 & 2921 & 24.2 & 20.2 & 12.0 & 9.6 & 19.72 & 18.35 \\
\hline & $0.6 \mathrm{~g} / \mathrm{L}$. & 3060 & 2698 & 23.8 & 20.0 & 10.6 & 8.2 & 20.32 & 19.24 \\
\hline \multirow{3}{*}{$\begin{array}{l}10 \mathrm{~m}^{3} \\
\text { P.W }\end{array}$} & Control & 2700 & 2505 & 20.8 & 18.9 & 8.9 & 8.3 & 20.32 & 19.97 \\
\hline & $0.4 \mathrm{~g} / \mathrm{L}$. & 3133 & 3053 & 26.7 & 22.6 & 11.7 & 9.1 & 19.38 & 18.18 \\
\hline & $0.6 \mathrm{~g} / \mathrm{L}$. & 2882 & 2828 & 25.8 & 22.5 & 11.4 & 8.3 & 20.03 & 18.82 \\
\hline \multirow{3}{*}{$\begin{array}{l}20 \mathrm{~m}^{3} \\
\text { P.W }\end{array}$} & Control & 2909 & 2656 & 22.5 & 20.6 & 9.3 & 9.0 & 20.30 & 20.43 \\
\hline & $0.4 \mathrm{~g} / \mathrm{L}$. & 3287 & 3216 & 27.4 & 23.4 & 12.3 & 9.8 & 19.54 & 18.53 \\
\hline & $0.6 \mathrm{~g} / \mathrm{L}$. & 3045 & 3029 & 26.6 & 23.1 & 11.8 & 9.0 & 20.11 & 19.15 \\
\hline \multirow{3}{*}{$\begin{array}{l}30 \mathrm{~m}^{3} \\
\text { P.W }\end{array}$} & Control & 3085 & 2798 & 23.2 & 21.2 & 9.6 & 9.0 & 20.82 & 20.61 \\
\hline & $0.4 \mathrm{~g} / \mathrm{L}$. & 3557 & 3405 & 28.2 & 24.2 & 12.9 & 11.0 & 19.94 & 18.95 \\
\hline & $0.6 \mathrm{~g} / \mathrm{L}$. & 3358 & 3196 & 27.9 & 23.9 & 12.1 & 9.0 & 20.58 & 19.60 \\
\hline \multicolumn{2}{|c|}{ LSD at $5 \%$} & 75 & N.S & N.S & N.S & N.S & N.S & N.S & 0.12 \\
\hline
\end{tabular}

A.W=Animal waste T.R.=Town refuse P.W = Plant waste C.T = Compost types $B=$ Boron

\section{2- Chemical composition of sugar beet:}

The results in Table (10) indicate that the highest values of sugar and crude protein percentage were recorded in plants treated with $30 \mathrm{~m}^{3} / \mathrm{fed}$. animal waste and the lowest value was attained by using $10 \mathrm{~m}^{3} / \mathrm{fed}$. town refuse in the two seasons. In all treatments increasing compost production from 10 to $30 \mathrm{~m}^{3} / \mathrm{fed}$. increased sugar and crude protein \% in plant tissues at the first and second seasons. While, the highest value of juice purity \% was obtained by using $30 \mathrm{~m}^{3} / \mathrm{fed}$. animal waste and $10 \mathrm{~m}^{3} / \mathrm{fed}$. town refuse at the first and second seasons, respectively. The lowest values of juice purity were recorded by using $10 \mathrm{~m}^{3} /$ fed. for town refuse and animal waste during the first and seasons, respectively. These results were reported by El-Nagdi and Abd El Fattah (2011) and Meherunnessa and Zakir (2011).

The results summarized in Table (11) show that application of boron fertilizer exerted a significant increase in sugar, juice purity and crude protein $\%$ in two seasons. Increasing boron spraying from 0 to $0.6 \mathrm{~g} / \mathrm{L}$. increased all 
chemical composition in the first and second seasons, except crude protein $\%(0.4 \mathrm{~g} / \mathrm{L}$.) gave the highest value of protein). On the other, hand the lowest value of chemical composition of sugar beet was obtained with control (without boron) during 2011/2012 and 2012/2013 seasons. These results are in agreement with those obtained by Vince (2010), Abido (2012) and Konthoujam et al. (2012).

The data illustrated in Table (12) reveal that the interaction between different compost types and boron foliar had a significant effect on sugar \% and crude protein \% in roots of sugar beet plants in the two growing seasons. While, juice purity \% was significant in second season. The maximum value of sugar \% was obtained by boron foliar at $0.6 \mathrm{~g} / \mathrm{L}$. with either $30 \mathrm{~m}^{3}$ animal waste / fed. in two seasons. While, the highest value of juice purity \% was obtained by adding animal waste as compost at rate $30 \mathrm{~m}^{3} /$ fed. with control (nil boron) in the first season, boron foliar application at $0.4 \mathrm{~g} / \mathrm{L}$. with $20 \mathrm{~m}^{3} /$ fed. town refuse gave the highest value of juice purity $\%$ in the second season. The maximum value of crude protein was obtained by boron foliar at $0.4 \mathrm{~g} / \mathrm{L}$. with either $30 \mathrm{~m}^{3}$ animal waste / fed. in both seasons.

Table (9). Root fresh and dry weight / plant and tops fresh and dry weight / plant of sugar beet at harvest as affected by interaction in 2011/2012 and 2012/2013 seasons at Ras Sudr.

\begin{tabular}{|c|c|c|c|c|c|c|c|c|c|}
\hline Che & aracters & $\begin{array}{r}\text { Root fr } \\
/ \mathrm{pl}\end{array}$ & $\begin{array}{l}\text { weight } \\
\text { (kg) }\end{array}$ & $\begin{array}{r}\text { Root d } \\
\text { pla }\end{array}$ & $\begin{array}{l}\text { veight / } \\
\text { kg) }\end{array}$ & $\begin{array}{r}\text { Top fre } \\
\text { pla }\end{array}$ & $\begin{array}{l}\text { weight / } \\
\text { kg) }\end{array}$ & $\begin{array}{r}\text { Top d } \\
\mathrm{pl}\end{array}$ & $\begin{array}{l}\text { eight / } \\
\text { kg) }\end{array}$ \\
\hline Interactio & & 2011/ & 2012/ & 2011/ & 2012/ & 2011/ & 2012/ & 2011/ & 2012/ \\
\hline C.T & B & & & & & & & & \\
\hline $10 \quad \mathrm{~m}^{3}$ & Control & 0.945 & 0.695 & 0.208 & 0.146 & 0.378 & 0.228 & 0.043 & 0.026 \\
\hline $\begin{array}{ll}10 & \mathrm{~m}\end{array}$ & $0.4 \mathrm{~g} / \mathrm{L}$ & 1.273 & 1.123 & 0.294 & 0.249 & 0.613 & 0.413 & 0.074 & 0.050 \\
\hline & $0.6 \mathrm{~g} / \mathrm{L}$ & 1.123 & 0.923 & 0.252 & 0.199 & 0.476 & 0.301 & 0.056 & 0.035 \\
\hline $20 \quad \mathrm{~m}^{3}$ & Control & 1.059 & 0.809 & 0.237 & 0.174 & 0.415 & 0.265 & 0.049 & 0.030 \\
\hline $20 \quad m^{3}$ & $0.4 \mathrm{~g} / \mathrm{L}$. & 1.407 & 1.257 & 0.329 & 0.285 & 0.655 & 0.455 & 0.080 & 0.056 \\
\hline & $0.6 \mathrm{~g} / \mathrm{L}$ & 1.298 & 1.098 & 0.295 & 0.243 & 0.525 & 0.35 & 0.063 & 0.041 \\
\hline $30 \quad \mathrm{~m}^{3}$ & Control & 1.205 & 0.955 & 0.274 & 0.213 & 0.474 & 0.324 & 0.057 & 0.038 \\
\hline $\begin{array}{ll}30 & m\end{array}$ & $0.4 \mathrm{~g} / \mathrm{L}$. & 1.575 & 1.425 & 0.372 & 0.333 & 0.697 & 0.497 & 0.087 & 0.062 \\
\hline & $0.6 \mathrm{~g} / \mathrm{L}$. & 1.445 & 1.245 & 0.335 & 0.284 & 0.575 & 0.400 & 0.070 & 0.048 \\
\hline & Control & 0.675 & 0.425 & 0.142 & 0.082 & 0.317 & 0.167 & 0.035 & 0.017 \\
\hline 10 & $0.4 \mathrm{~g} / \mathrm{L}$ & 0.899 & 0.749 & 0.197 & 0.157 & 0.515 & 0.315 & 0.059 & 0.034 \\
\hline & $0.6 \mathrm{~g} / \mathrm{L}$. & 0.797 & 0.597 & 0.172 & 0.123 & 0.429 & 0.254 & 0.047 & 0.027 \\
\hline & Control & 0.764 & 0.514 & 0.164 & 0.103 & 0.359 & 0.209 & 0.040 & 0.022 \\
\hline 2 & $0.4 \mathrm{~g} / \mathrm{L}$. & 1.039 & 0.889 & 0.232 & 0.191 & 0.539 & 0.339 & 0.063 & 0.038 \\
\hline & $0.6 \mathrm{~g} / \mathrm{L}$. & 0.915 & 0.715 & 0.201 & 0.150 & 0.458 & 0.283 & 0.052 & 0.031 \\
\hline & Control & 0.848 & 0.598 & 0.185 & 0.124 & 0.401 & 0.251 & 0.046 & 0.028 \\
\hline 30 & $0.4 \mathrm{~g} / \mathrm{L}$. & 1.191 & 1.041 & 0.27 & 0.230 & 0.573 & 0.373 & 0.069 & 0.044 \\
\hline & $0.6 \mathrm{~g} / \mathrm{L}$. & 1.023 & 0.823 & 0.227 & 0.176 & 0.485 & 0.310 & 0.056 & 0.035 \\
\hline & Control & 0.809 & 0.559 & 0.175 & 0.116 & 0.354 & 0.204 & 0.040 & 0.022 \\
\hline 10 & $0.4 \mathrm{~g} / \mathrm{L}$. & 1.185 & 1.035 & 0.265 & 0.225 & 0.552 & 0.352 & 0.065 & 0.039 \\
\hline & $0.6 \mathrm{~g} / \mathrm{L}$. & 1.021 & 0.821 & 0.225 & 0.173 & 0.469 & 0.294 & 0.054 & 0.032 \\
\hline & Control & 0.949 & 0.699 & 0.209 & 0.147 & 0.387 & 0.237 & 0.044 & 0.026 \\
\hline 20 & $0.4 \mathrm{~g} / \mathrm{L}$. & 1.254 & 1.104 & 0.284 & 0.246 & 0.585 & 0.385 & 0.071 & 0.044 \\
\hline & $0.6 \mathrm{~g} / \mathrm{L}$ & 1.165 & 0.965 & 0.261 & 0.211 & 0.496 & 0.321 & 0.058 & 0.036 \\
\hline & Control & 1.085 & 0.835 & 0.242 & 0.180 & 0.422 & 0.272 & 0.049 & 0.031 \\
\hline 30 & $0.4 \mathrm{~g} / \mathrm{L}$. & 1.383 & 1.233 & 0.319 & 0.281 & 0.613 & 0.413 & 0.076 & 0.050 \\
\hline & $0.6 \mathrm{~g} / \mathrm{L}$. & 1.275 & 1.075 & 0.29 & 0.24 & 0.536 & 0.361 & 0.064 & 0.042 \\
\hline LSD at $5 \%$ & & N.S & N.S & N.S & N.S & N.S & N.S & N.S & 0.004 \\
\hline
\end{tabular}

A.W=Animal waste T.R.=Town refuse P.W=Plant waste C.T = Compost types B = Boron 
Table (10). Sugar \%, juice purity \%, Crude protein $\%$, and boron $(\mathrm{mg} / \mathrm{kg})$ of sugar beet roots at harvest as affected by compost types in 2011/2012 and 2012/2013 seasons at Ras Sudr.

\begin{tabular}{|c|c|c|c|}
\hline Characters & $\begin{array}{c}\text { Sugar } \\
\%\end{array}$ & Juice purity \% & Crude protein \% \\
\hline \multicolumn{4}{|c|}{ Compost types } \\
\hline $10 \mathrm{~m}^{3}$ A.W & 17.17 & 85.33 & 10.42 \\
\hline $20 \mathrm{~m}^{3}$ A.W & 17.70 & 86.96 & 10.71 \\
\hline $30 \mathrm{~m}^{3}$ A.W & 18.17 & 87.58 & 11.14 \\
\hline $10 \mathrm{~m}^{3}$ T.R & 15.67 & 77.89 & 9.77 \\
\hline $20 \mathrm{~m}^{3}$ T.R & 16.20 & 81.64 & 10.10 \\
\hline $30 \mathrm{~m}^{3}$ T.R & 16.74 & 82.75 & 10.40 \\
\hline $10 \mathrm{~m}^{3}$ P.W & 15.87 & 79.67 & 10.04 \\
\hline $20 \mathrm{~m}^{3}$ P.W & 16.54 & 82.77 & 10.35 \\
\hline $30 \mathrm{~m}^{3}$ P.W & 17.03 & 83.29 & 10.79 \\
\hline LSD at $5 \%$ & 0.09 & 1.52 & 0.07 \\
\hline $10 \mathrm{~m}^{3}$ A.W & 16.64 & 85.35 & 9.57 \\
\hline $20 \mathrm{~m}^{3}$ A.W & 16.87 & 85.39 & 9.82 \\
\hline $30 \mathrm{~m}^{3}$ A.W & 17.16 & 85.50 & 9.99 \\
\hline $10 \mathrm{~m}^{3}$ T.R & 15.94 & 86.21 & 8.98 \\
\hline $20 \mathrm{~m}^{3}$ T.R & 16.26 & 86.10 & 9.22 \\
\hline $30 \mathrm{~m}^{3}$ T.R & 16.57 & 86.02 & 9.51 \\
\hline $10 \mathrm{~m}^{3}$ P.W & 16.28 & 85.78 & 9.26 \\
\hline $20 \mathrm{~m}^{3}$ P.W & 16.59 & 85.73 & 9.57 \\
\hline $30 \mathrm{~m}^{3}$ P.W & 16.90 & 85.73 & 9.80 \\
\hline LSD at $5 \%$ & 0.06 & 0.37 & 0.05 \\
\hline
\end{tabular}

A.W = Animal waste $\quad$ T.R. = Town refuse $\quad$ P.W = Plant waste

Table (11). Sugar \%, juice purity \%, Crude protein \%, and boron $(\mathrm{mg} / \mathrm{kg})$ of sugar beet roots at harvest as affected by boron spraying in 2011/2012 and 2012/2013 seasons at Ras Sudr.

\begin{tabular}{|l|c|c|c|}
\hline Characters & $\begin{array}{c}\text { Sugar } \\
\%\end{array}$ & Juice purity \% & Crude protein \% \\
\hline Boron spraying & \multicolumn{3}{|c|}{$\mathbf{2 0 1 1 / 2 0 1 2}$} \\
\hline Control & 16.06 & 81.42 & 10.00 \\
\hline $0.4 \mathrm{~g} / \mathrm{L}$. & 16.86 & 82.93 & 10.77 \\
\hline $0.6 \mathrm{~g} / \mathrm{L}$. & 17.45 & 84.94 & 10.47 \\
\hline LSD at 5\% & $\mathbf{0 . 0 4}$ & $\mathbf{0 . 4 5}$ & $\mathbf{0 . 0 4}$ \\
\hline \multicolumn{4}{|c|}{$\mathbf{2 0 1 2 / 2 0 1 3}$} \\
\hline Control & 16.23 & 83.18 & 9.05 \\
\hline $0.4 \mathrm{~g} / \mathrm{L}$. & 16.61 & 86.40 & 10.20 \\
\hline $0.6 \mathrm{~g} / \mathrm{L}$. & 16.89 & 87.70 & 9.36 \\
\hline LSD at 5\% & $\mathbf{0 . 0 4}$ & $\mathbf{0 . 7 2}$ & $\mathbf{0 . 0 4}$ \\
\hline
\end{tabular}

A.W = Animal waste $\quad$ T.R. $=$ Town refuse $\quad$ P.W = Plant waste 
Table (12). Sugar \%, juice purity \%, Crude protein $\%$, and boron $(\mathrm{mg} / \mathrm{kg})$ of sugar beet roots at harvest as affected by interaction in 2011/2012 and 2012/2013 seasons at Ras Sudr.

\begin{tabular}{|c|c|c|c|c|c|c|c|}
\hline \multirow{2}{*}{\multicolumn{2}{|c|}{ Interaction }} & \multicolumn{2}{|c|}{$\begin{array}{c}\text { Sugar } \\
\%\end{array}$} & \multicolumn{2}{|c|}{ Juice purity \% } & \multicolumn{2}{|c|}{ Crude protein $\%$} \\
\hline & & \multirow{2}{*}{$\begin{array}{l}2011 / \\
2012\end{array}$} & \multirow{2}{*}{$\begin{array}{c}2012 / \\
2013\end{array}$} & \multirow{2}{*}{$\begin{array}{c}2011 / \\
2012\end{array}$} & \multirow{2}{*}{$\begin{array}{l}2012 / \\
2013\end{array}$} & \multirow{2}{*}{$\begin{array}{l}2011 / \\
2012\end{array}$} & \multirow{2}{*}{$\begin{array}{l}2012 / \\
2013\end{array}$} \\
\hline C.T & $\mathrm{B}$ & & & & & & \\
\hline \multirow{3}{*}{${ }_{\text {A.W }}^{10} \mathrm{~m}^{3}$} & Control & 17.93 & 16.88 & 88.39 & 81.97 & 9.81 & 9.18 \\
\hline & $0.4 \mathrm{~g} / \mathrm{L}$. & 16.37 & 16.31 & 83.40 & 87.25 & 10.85 & 10.28 \\
\hline & $0.6 \mathrm{~g} / \mathrm{L}$. & 17.20 & 16.72 & 84.22 & 86.84 & 10.61 & 9.25 \\
\hline \multirow{3}{*}{${ }_{\text {A.W }}^{20} \mathrm{~m}^{3}$} & Control & 18.37 & 17.15 & 88.54 & 82.69 & 10.28 & 9.42 \\
\hline & $0.4 \mathrm{~g} / \mathrm{L}$. & 16.90 & 16.60 & 84.39 & 87.35 & 11.11 & 10.50 \\
\hline & $0.6 \mathrm{~g} / \mathrm{L}$. & 17.83 & 16.86 & 87.94 & 86.13 & 10.75 & 9.54 \\
\hline \multirow{3}{*}{$\begin{array}{l}30 \mathrm{~m}^{3} \\
\text { A.W }\end{array}$} & Control & 18.73 & 17.40 & 88.97 & 83.07 & 10.97 & 9.31 \\
\hline & $0.4 \mathrm{~g} / \mathrm{L}$. & 17.60 & 16.85 & 86.42 & 86.99 & 11.41 & 10.66 \\
\hline & $0.6 \mathrm{~g} / \mathrm{L}$. & 18.17 & 17.22 & 87.34 & 86.43 & 11.05 & 10.01 \\
\hline \multirow{3}{*}{$\begin{array}{l}10 \mathrm{~m}^{3} \\
\text { T.R }\end{array}$} & Control & 16.27 & 16.39 & 79.52 & 83.99 & 9.40 & 8.51 \\
\hline & $0.4 \mathrm{~g} / \mathrm{L}$. & 14.90 & 15.44 & 76.27 & 87.93 & 10.08 & 9.59 \\
\hline & $0.6 \mathrm{~g} / \mathrm{L}$. & 15.83 & 15.99 & 77.87 & 86.71 & 9.82 & 8.85 \\
\hline \multirow{3}{*}{$\begin{array}{ll}20 & \mathrm{~m}^{3} \\
\text { T.R } & \end{array}$} & Control & 16.97 & 16.65 & 83.95 & 84.40 & 9.64 & 8.77 \\
\hline & $0.4 \mathrm{~g} / \mathrm{L}$. & 15.50 & 15.85 & 80.48 & 88.32 & 10.39 & 9.83 \\
\hline & $0.6 \mathrm{~g} / \mathrm{L}$. & 16.13 & 16.28 & 80.48 & 85.60 & 10.26 & 9.07 \\
\hline \multirow{3}{*}{$\begin{array}{ll}30 & \mathrm{~m}^{3} \\
\text { T.R } & \end{array}$} & Control & 17.33 & 16.89 & 83.97 & 83.42 & 10.06 & 9.04 \\
\hline & $0.4 \mathrm{~g} / \mathrm{L}$. & 15.97 & 16.19 & 80.95 & 88.28 & 10.59 & 10.14 \\
\hline & $0.6 \mathrm{~g} / \mathrm{L}$. & 16.93 & 16.62 & 83.33 & 86.37 & 10.55 & 9.35 \\
\hline \multirow{3}{*}{$\begin{array}{l}10 \mathrm{~m}^{3} \\
\text { P.W }\end{array}$} & Control & 16.37 & 16.52 & 80.53 & 82.71 & 9.49 & 8.73 \\
\hline & $0.4 \mathrm{~g} / \mathrm{L}$. & 15.23 & 15.96 & 78.59 & 87.78 & 10.60 & 9.89 \\
\hline & $0.6 \mathrm{~g} / \mathrm{L}$. & 16.00 & 16.35 & 79.87 & 86.86 & 10.04 & 9.14 \\
\hline \multirow{3}{*}{$\begin{array}{l}20 \\
\text { P.W }\end{array} \mathrm{m}^{3}$} & Control & 17.37 & 16.91 & 85.55 & 82.75 & 9.90 & 9.08 \\
\hline & $0.4 \mathrm{~g} / \mathrm{L}$. & 15.67 & 16.30 & 80.19 & 87.95 & 10.80 & 10.24 \\
\hline & $0.6 \mathrm{~g} / \mathrm{L}$. & 16.60 & 16.57 & 82.57 & 86.50 & 10.37 & 9.39 \\
\hline \multirow{3}{*}{$\begin{array}{l}30 \mathrm{~m}^{3} \\
\text { P.W }\end{array}$} & Control & 17.70 & 17.23 & 85.02 & 83.6 & 10.48 & 9.37 \\
\hline & $0.4 \mathrm{~g} / \mathrm{L}$. & 16.37 & 16.57 & 82.07 & 87.46 & 11.10 & 10.40 \\
\hline & $0.6 \mathrm{~g} / \mathrm{L}$. & 17.03 & 16.88 & 82.77 & 86.12 & 10.79 & 9.64 \\
\hline \multicolumn{2}{|c|}{ LSD at $5 \%$} & 0.16 & 0.10 & N.S & 0.67 & 0.48 & 0.08 \\
\hline
\end{tabular}

A.W = Animal waste T.R.=Town refuse P.W=Plant waste C.T=Compost types $B=$ Boron

\section{REFERENCES}

Abido, W.A.E. (2012). Sugar beet productivity as affected by foliar spraying with methanol and boron. Inter. J. of Agric. Sci., 4 (7): 287-292.

Abou EL-Yazied, A. and M.A. Mady. (2012). Effect of boron and yeast extract foliar application on growth, pod setting and both green pod and seed yield of broad bean(Vicia faba L.).J.of Applied Sci.,Res,8(2):12401251.

Aparna, H. and E.T. Puttaiah. (2012). Residual effect of zinc and boron on growth and yield of french bean (Phaseolus vulgaris L.)-rice (Oryza sativa L.) cropping system. Inter. J. of Envi. Sci., 3 (1): 167-171.

Carruthers, A. and J.F.T. Oldfield (1961). Methods for the assessment of beet quality. International Sugar journal, 63: 72-74.

El-Nagdi, W.M.A. and A.I. Abd El Fattah. (2011). Controlling root-knot nematode, meloidogyne incognita infecting sugar beet using some plant residues, a biofertilizer, compost and biocides. J. of Plant Protection Research. 51 (2): 107-113. 
El-Quesni, F.E.M.; Kh.I. Hashish, M. M. Kandil and A. A.M. Mazher. (2013). Impact of some biofertilizers and compost on growth and chemical composition of Jatropha curcas L. World Applied Sci., J. 21 (6): 927932.

Esawy, M.; N. Abd EL- Kader, P. Robin, N. Akkal-Corfini and L. Abd ElRahman. (2009). Effects of different organic and inorganic fertilizers on cucumber yield and some soil properties. World J. of Agric, Sci., 5 (4): 408-414.

Essam E.S.; A.A. Mohamed, T.T. Alice and M.I. Omar (2011). Effect of potassium and organic fertilizer on growth and yield of some sugar beet varieties grown under saline conditions .J. of Agric. and Bio. Sci., 1(2): 1-8.

Ibrahim, B.S. (2006). Sugar beet types and some micro-elements in relation to yield and quality. M. Sc. Thesis, Fac. Agric., Moshtohor, Zagazig Univ., Benha Branch, Egypt.

Ismail, A.E. and M.M. Mohamed (2012). Nematicidal potentiality of some animal manures combined with urea against meloidogyne arenaria and growth and productivity of sugar beet under field conditions. Pak. J. Nematol., 30 (1): 57-65.

Jackson, M.L. (1970). "Soil Chemical Analysis" The Eng. Long Book Soc. New Delhi, India.

Konthoujam, N.D.; L.N.K. Singh, M.S. Singh, S.B. Singh and K.K. Singh. (2012). Influence of sulphur and boron fertilization on yield, quality, nutrient uptake and economics of soybean (Glycine max) under upland conditions. J. of Agric. Sci., 4 (4): 1-10.

Le Docta, A. (1927). Commercial determination of sugar in the beet root using the sachs - Le Docta process, Int. Sug. J.,29: 488-492 (C. F. Sugar Beet Nutrition, April 1972 Applied Science Publishers LTD, London A. P. Draycott).

Luna Z.H.S.; S.O. Myrna, L.W. Wenndy, V.R. Andrea and G.P.J. Manuel. (2011). Effects of compost made with sludge and organic residues on bean (Phaseolus vulgaris L.) crop and arbuscular mycorrhizal fungi density. 6 (6): 1580-1585.

Meherunnessa, N.M.T. and H.M. Zakir (2011). Influence of compost and fertilizers on growth, yield and some biochemical composition on summer tomato. Bangladesh Research Publications Journal. 5 (4): 344 -350 .

Peach, K. and M.R. Tracey (1956). Modern methods plant analysis Vol.1 Springer Verlage, Berlin, 4: 643.

Ramadan, A. M. Hashem and S. Alamri (2013). Effect of soil amendment with yeasts as bio-fertilizers on the growth and productivity of sugar beet. African J. of Agric. Res., 8(1): 46-56.

Snedecor, G.W. and W.G. Cochran (1969). "Statistical Methods". $6^{\text {th }}$ ed. lowa State Univ., Press, Ames, lowa, U.S.A.

Steel, G.D.R. (1960). "Principles and procedures of statistics". New York McGraw-Hill Book Co., pp. 481. 
Tabrizi, E.F.M.; M. Yarnia, M.B. Khorshidi and F.R. Khoei (2008). Effect of foliar $\mathrm{N}$ and $\mathrm{B}$ application at different growth stages of sugar beet cultivars on root and sugar yield, sugar percent and root dry matter. J. of Food, Agric. \& Envr. 6 (3 and 4): 253 - 255.

Vince, L. (2010). Effect of boron fertilizer on sugar beet grown on fruitfield sand soil. lowa State University, Muscatine Island Research and Demonstration Farm. pp 9-20.

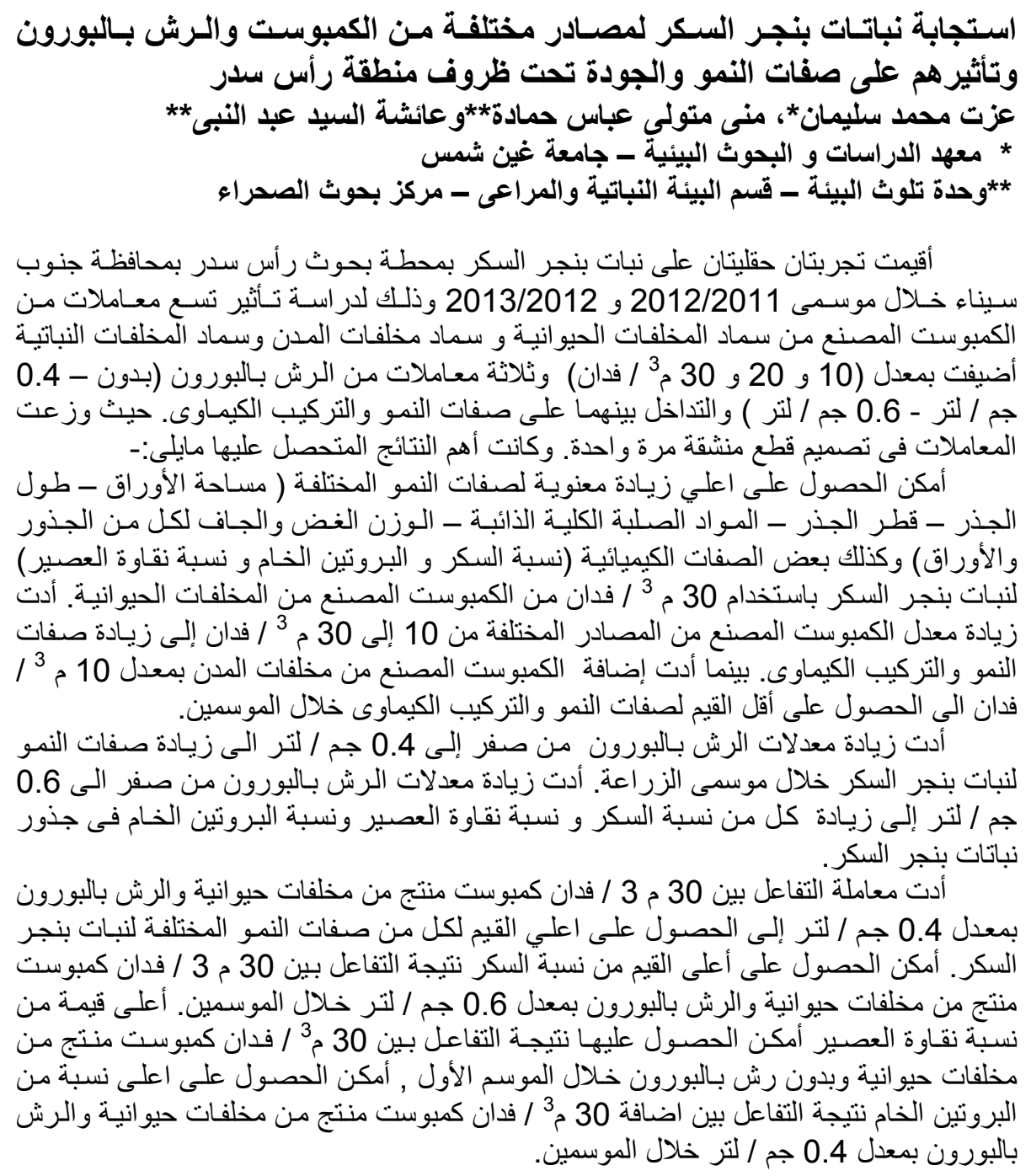

